\title{
Establishment and some Biological Characteristics of a Cell Line Derived from Yamame Embryonal Liver
}

\author{
Tadaaki Moritomo, ${ }^{*}$ Hiroyoshi Asakawa,* Masanori Nakano,* \\ and Tasuku Watanabe*
}

(Received April 25, 1988)

\begin{abstract}
We tried to cultivate fish liver cells using the embryonated eggs of Yamame, landlocked form of masu salmon, Oncorhynchus masou. A continuous cell line designated YEL-13 was established and has been subcultured more than 120 times over the period of 3 years. YEL-13 cells grow in the manner of contact inhibited monolayer and consisted of epithelial cells and a few fibrobrastic cells. Electron microscopically, most of the cells had a large and round nucleus and well- developed rough surfaced endoplasmic reticulum in cytoplasm and smooth cell surface with poorly developed microvilli. Chromosme number of YEL-13 ranged widely and most of them were between 50 and 83 . The cells with 56 chromosomes occupied $24 \%$ of those examined. YEL-13 cells have the permissible temperature range of $15-20^{\circ} \mathrm{C}$ for growth. The cell line has been producing and relaesing a Yamame serum protein constantly which is one of the main functions of liver parenchymal cells.
\end{abstract}

In vitro cultivation of liver cells $w$ ith functional characteristics common to in vivo liver cells is of potential value in many investigations. In recent years, there have been many attempts to cultivate liver cells using the liver tissues of mammals and lower vertebrates ${ }^{13}$ including fish. ${ }^{*, 3}$ ) Several continuous cell lines have been obtained firom the liver of mammals, ${ }^{4.5}$ amphibian ${ }^{13}$ and fish. Some of them retain several specific liver functions. ${ }^{5,8)}$ These cell lines are available in various studies such as cell differentiations, malignant transformation, or cell metabolisms." ${ }^{\text {"11 }}$

Recently, the importance of the functional cell culture, especially liver cell culture of fish have been recognized in the research field of fisheries sciences. Cultured fish liver cells will give us a good tool in studying physiology and biochemistry of fish liver. We tried to establish a cell line which had a differentiated liver function using embryonated eggs of Yamame, landlocked form of masu salmon Oncorhynchus masou indigenous to Japan.

\section{Materials and Methods}

\section{Cell Culture}

The embryonated eggs of Yamame obtained from Yamaguchi Fish Farm, Yamanasi. Upon the confirmation of few eggs hatched, eggs were dipped in a solutions containing $100 \mathrm{I} . \mathrm{U} . / \mathrm{m} /$ of penicillin $G$ potassium for $24 \mathrm{~h}$. After the surface of eggs was disinfected with $70 \%$ ethanol, egg membrane and yolk were removed under binocular microscope (Fig. 1). Liver tissues were transferred in sterilized petri dishes and minced into small fragments with scissors in small amount of TC199 medium supplemented with $10 \%$ fetal bovine serum (199-10), transferred into plastic tissue culture flask (Corning Glass Work, NY, USA) and then cultivated at $20^{\circ} \mathrm{C}$. One half of the medium was replaced by fresh one twice a week throughout the period of primary culture. Each flask contained liver cells derived from 3-5 eggs for the primary culture and were designated YEL-. When cells grew to form confluent monolayer cell sheet, cells were trypsinized, and reseeded at the density of $1-3: 10^{5}$ cells per flask. The doubling time (D.T.) was calculated as described previously. ${ }^{12}$ The cells after 20th passage were cultivated with Eagle's minimum essential medium supplemented with $10 \%$ fetal bovine serum (MEM-10).

\section{Chromosome Number}

The cells between 85th and 90th passage of YEL-13 were used. Colchicine (Sigma, Mo., USA) was added in cultured medium to be a final concentration of $0.1 / \mathrm{g}$ per $\mathrm{m} l$. After in-

* Department of Veterinary Science, Nihon university, Kameino, Fujisawa 252, Japan (森友忠昭, 浅

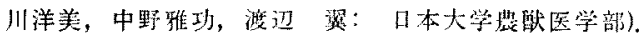



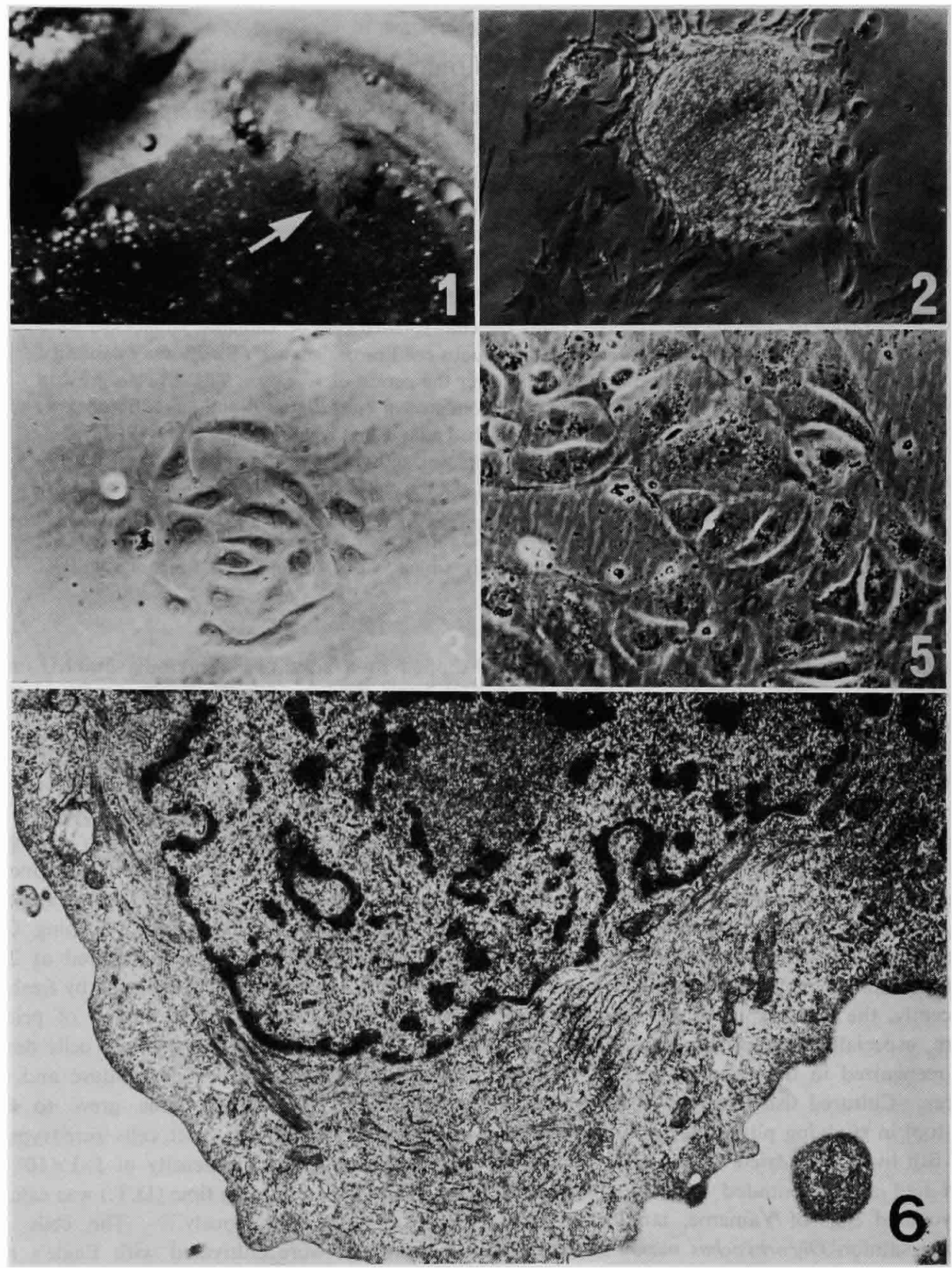

Fig. 1. Yamame embryo after removing the egg membrane and yolk. Arrow indicates liver.

Fig. 2. Phase contrast micrograph of the primary culture of Yamame embryonal liver 2 days after incubation. The cells migrating from tissue fragment.

Fig. 3. Phase contrast micrograph of the primaty culture of Yamame embronal liver 4 day after incubation. Small colony of epithelial cells.

Fig. 5. Monolayer cell sheet of YEL-13 cells, consisting of large epithelial cells and a few fibroblastic spindle-shaped cells.

Fig. 6. Electron micrograph of one of the typical YEL-13 cells. The cells had smooth surface with poorly developed microvilli and well-developed rouh surfaced endoplasmic reticulum. $\times 17000$ 
cubated with the colchicine medium for $24 \mathrm{~h}$ at $20^{\circ} \mathrm{C}$, the cells were trypsinized and treated with $0.075 \mathrm{M} \mathrm{KCl}$ hypotonic solution for $40 \mathrm{~min}$. After swelling the cells were fixed with acetic acidmethanol $(1: 3)$ and stained with Giemsa solution.

\section{Growth Rate}

Five $\times 10^{5}$ cells of YEL-13 were seeded in tissue culture glass tubes and incubated at 10, 15, 20, and $25^{\circ} \mathrm{C}$. Cell numbers were counted triplicate tubes on the 2 nd, 4 th, 7 th, 11 th, 15th, 19th and 23rd culture days. The media were renewed every second day. The growth curve of the cultured YEL-13 cells were made and compared at each temperature.

\section{Immunological Methods}

Rabbit antiserum against Yamame serum was prepared by intravenous injections at intervals of 7 days for 4 times and collected at the 7 th day after the last injection. Antiserum was heated at $63^{\circ} \mathrm{C}$ for $20 \mathrm{~min}$ before use.

For indirect fluorescent antibody methods, YEL-13 cells were grown on glass coverslips for two days, fixed in cold acetone and stored at $-20^{\circ} \mathrm{C}$ until use. In the staining procedures, diluted antiserum was applied to the cells for $1 \mathrm{~h}$. After washing with phosphate buffered saline $(\mathrm{pH}$ 7.4 , PBS), the cells were overlaid with a solutions of FITC-conjugated goat IgG against rabbit $\operatorname{lgG}$ (Cappel Labo. Inc., USA) for another $1 \mathrm{~h}$. Then, the cells were washed with PBS again and examined with a fluorescence microscope.

Cultured media, which had been in contact with the cells of YEL-8, 12 or 13 for 7 days, were harvested, pooled, concentrated 10 times and stored at $-20^{\circ} \mathrm{C}$ until use. These concetrated cultured media were examined by immunodiffusion and immunoelectrophoresis using the methods described by Ouchterlony and Nillson with anti-Yamame whole serum. ${ }^{13)}$ Fetal bovine serum (FBS) and Yamame whole serum were used in both examinations as control.

\section{Results}

\section{Primary Cell Culture}

Flasks seeded with Yamame embryonated liver cells were observed daily with a phase contrast tissue culture microscope. Two day after the primary culture, epithelial and fibroblastic cells were observed migrating from tissue fragments in every flask (Fig. 2). After 3-4 days, several colonies consisted of epithelial cells were observed in various parts of the flasks (Fig. 3). These epithelial cells were multiplied to form colonies and terminated the growth in the manner of contact-inhibited monolayer in 28-38th day of primary cell culture. These colonies were trypsinized and reseeded in new flasks. Cell growth was not observed in 8 flasks, and fibroblastic cells grew and were predominant in other 2 flasks (Table 1).

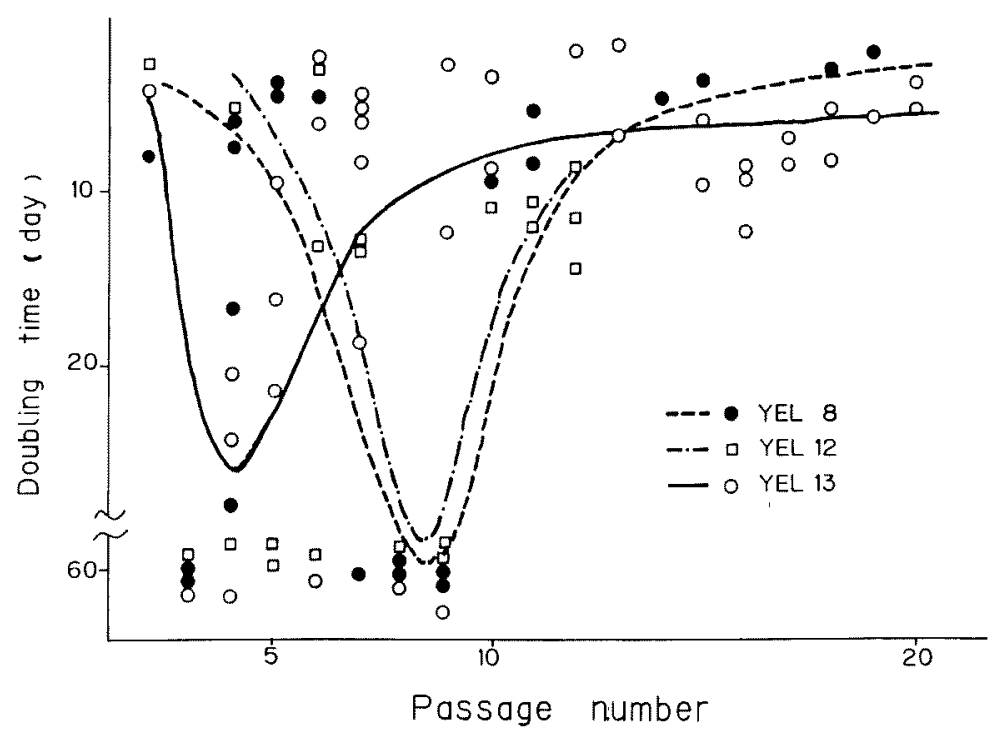

Fig. 4. Doubling times and passages of YEL-cells from 2nd to 20th culture. 

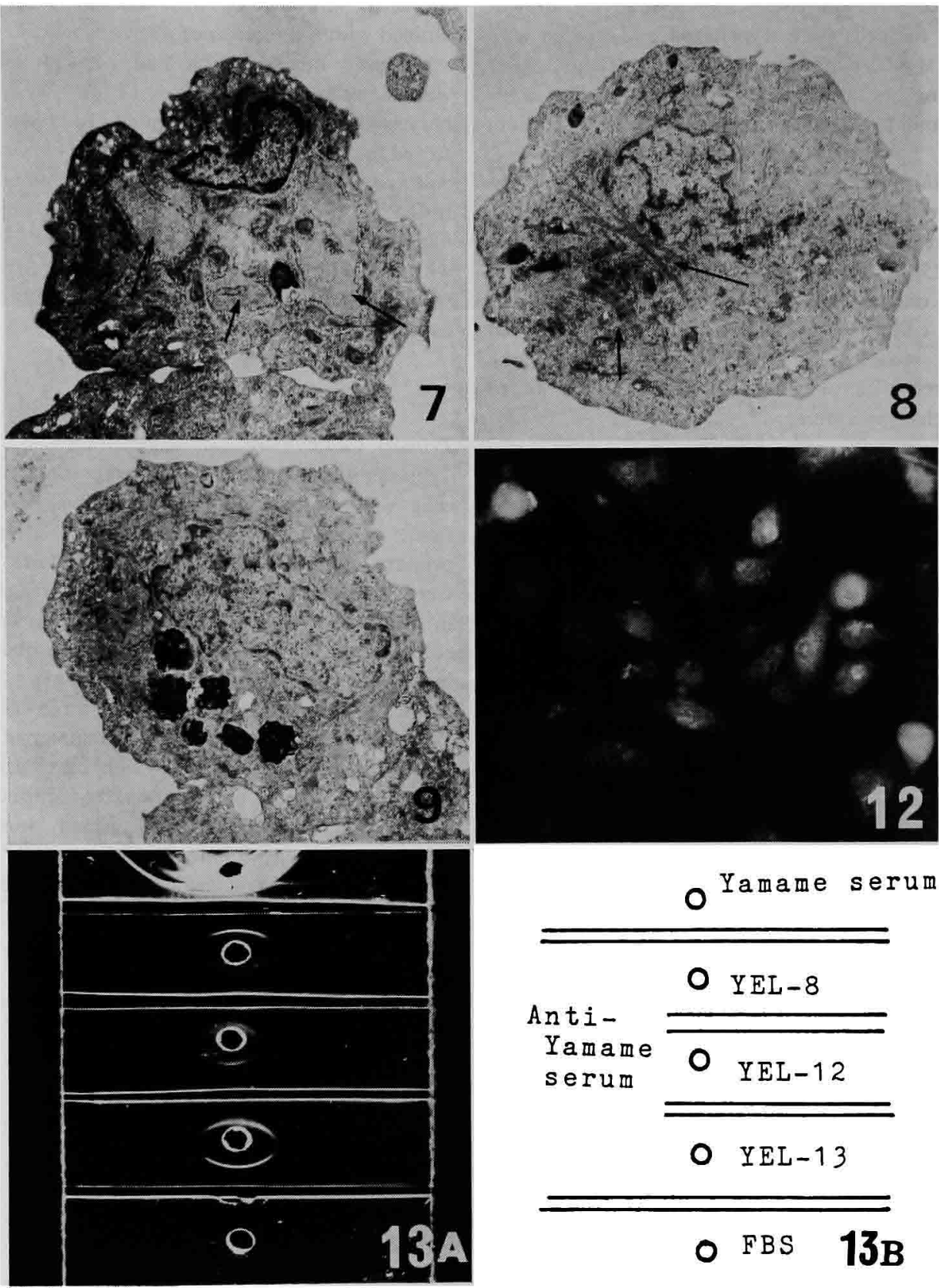

Yamame serum

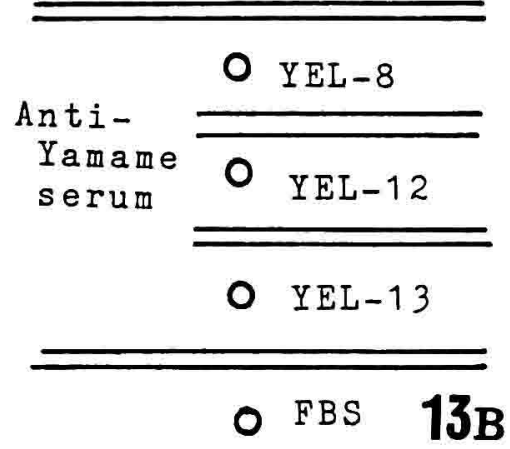

Fig. 7. Electron micrograph of a YEL-13 cell. Note the expanded rough surfaced endoplasmic reticulum (arrows). $\quad \times 9300$

Fig. 8. Electron micrograph of a YEL-13 cell. Note the filaments in the cytoplasm (arrows). $\times 7500$

Fig. 9. Electron micrograph of a YEL-13 cell. Extensive electron-densed granules were observed in the leaf border of cytoplasm. $\times 6200$

Fig. 12. Immunofluorescent micrograph of YEL-13 cells. The cytoplasm were stained intensely by immunofluorescence with antiserum to Yamame serum.

Fig. 13. Immunoelectrophresis of the mediums of YEL-cells (A) and diagram (B). 
Table 1. Culture of Yamame embryonated liver cells

\begin{tabular}{|c|c|c|}
\hline $\begin{array}{c}\text { Flask } \\
\text { number }\end{array}$ & $\begin{array}{c}\text { Period of } \\
\text { primary culture } \\
\text { (days) }\end{array}$ & $\begin{array}{l}\text { Passage number } \\
\text { in } \\
\text { 10th May, } 1988\end{array}$ \\
\hline YEL- 1 & - & \\
\hline YEL- 2 & - & \\
\hline YEL- 3 & 37 & \\
\hline YEL- 4 & $33(F)$ & \\
\hline YEL- 5 & - & \\
\hline YEL- 6 & 38 & \\
\hline YEL- 7 & 38 & 14 \\
\hline YEL- 8 & 38 & 40 \\
\hline YEL- 9 & 29 & \\
\hline YEL-10 & - & \\
\hline YEL-11 & 32 & \\
\hline YEL-12 & 29 & 21 \\
\hline YEL-13 & 28 & 120 \\
\hline YEL-14 & 30 & \\
\hline YEL-15 & 27 & 16 \\
\hline YEL-16 & - & \\
\hline YEL-17 & 28 & 20 \\
\hline YEL-18 & - & \\
\hline YEL-19 & $21(F)$ & \\
\hline YEL-20 & - & \\
\hline YEL-21 & 26 & \\
\hline YEL-22 & - & \\
\hline
\end{tabular}

\section{Passage of YEL}

Secondarily passaged seven flasks, YEL-6, -7, $-8,-12,-13,-15$ and -17 showed epithelial morphology and grew rapidly to form a monolayer cell sheet until contact-inhibition restricted the growth. Fig. 4 shows the relationships between the doubling time and passage numbers of YEL-
$8,-12$, and -13 . From the 3rd to 9th passage, cell growth of YEL-13 was quite slow. But the cells had shortened their doubling time gradually, and were able to be transferred at the intervals of 7-10 days after 10 passages. Cell growth of YEL-8 and -12 became slowly from 8 th to 9 th passage. But after then, growth of the cells were getting fast like YEL-13. As shown in Table 1, these cells were subcultured for 14 to 125 until April, 1988. YEL-13 has been subcultured for 125 times from its initiation in October, 1984.

\section{Morphology of YEL-13}

YEL-13 cells grew on the manner of contact inhibited monolayer until the formations of confluent cell sheets. The cells consisted of epithelial cells with round nucleus and aboundant granular intracytoplasmic organelle suspected to be mitochondria (Fig. 5), A few fibroblastic spindleshaped cells with small oval nucleus were observed.

Electron microscopically, most of the YEL-13 had a large and round nucleus and cell surface with poorly developed microvilli and well-developed rough surfaced endoplasmic reticulum (rER) in cytoplasm (Fig. 6). Some of these cells had expanded rER (Fig. 7). There were a few cells with an elongated nucleus often deeply indented and small filaments in cytoplasm as shown in Fig. 8. In the cytoplasms of those cells, numerous ribosomes were observed. And some of them had extensive electron-densed granules in the border of cytoplasm as shown in Fig. 9.

\section{Chromosome Number}

Fig. 10 represents the chromosomal distribu-

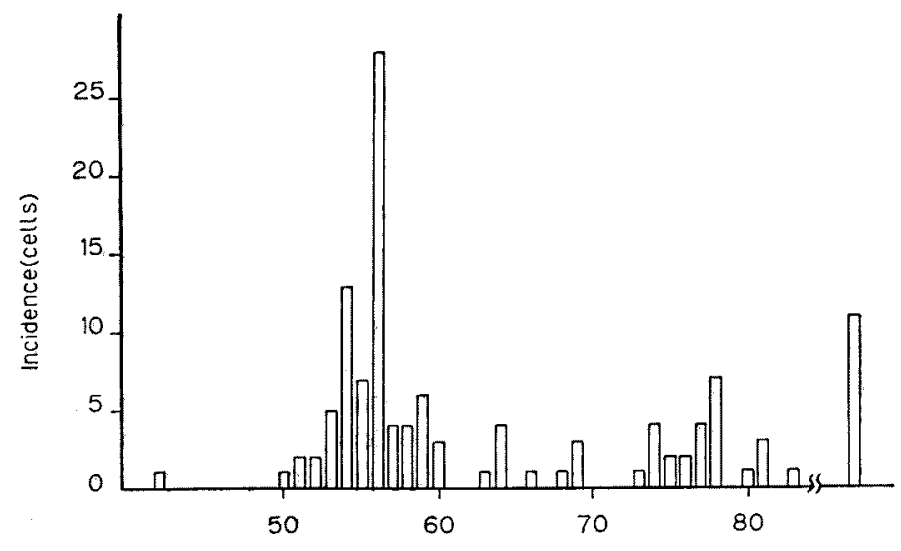

Chromosome numbers

Fig. 10. Chromosome numbers of YEL-13 cells in colchicine metaphase. 


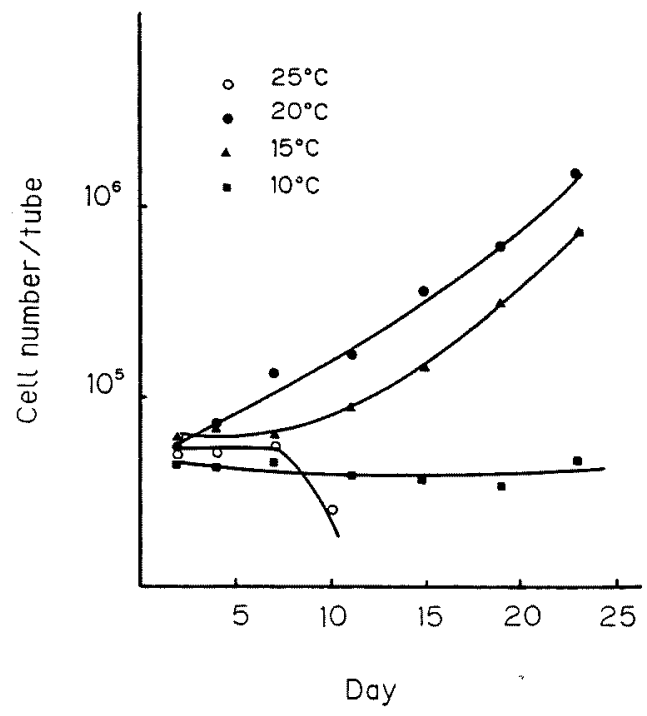

Fig. 11. Growth curve of YEL-13 at various temparature.

tion patterns of YEL-13. Chromosome number of YEL-13 ranged widely and most of them were between 50 to 83 . Count were made on 118 cells and $64 \%$ of them had chromosomes between 50 and 60 . The cells with 56 chromosomes were $24 \%$ counted cell. Occasionally, tetraploid-like cells with more than 100 chromosomes were observed.

\section{Protein Synthesis by YEL Cells}

YEL-13 cells were examined under a fluoresent microscope, after reacting with rabbit serum against Yamame serum and with FITC-conjugated goat IgG against rabbite IgG. As shown in Fig. 12, the cytoplasm of YEL-13 was stained intensely by immunofluorescence with antiserum against Yamame serum.

A Yamame serum protein was deteected in the concentrated culture medium, which were harvested from YEL-8, -12, and YEL-13 by immunoelectrophoretic study. As shown in Fig. 13, only one precipitating line was observed between these medium and antiserum against Yamame serum. No precipitating line was observed between FBS and antiserum. The double diffusion tests also showed that one of the serum protein were produced and released by YEL-8, -12, and -13 .

Growth Rate of YEL-13 at Various Temperature

Fig. 11 represents the growth curve of YEL-13 cells at various temprature. YEL-13 cells grew between $15^{\circ} \mathrm{C}$ and $20^{\circ} \mathrm{C}$ and grew most rapidly at $20^{\circ} \mathrm{C}$. But at $25^{\circ} \mathrm{C}$, all of the cells came off from the surface of the culture tubes within 10 days. Low temperature less than $10^{\circ} \mathrm{C}$ inhibited the cell growth of YEL-13.

\section{Discussion}

We succeeded in culturing liver cells from embryonated egg of Yamame for long period. Cells of YEL-7, -8, -13, -15, and -17 grew rapidly and were transferable. Of them, YEL-13 has been subcultured more than 120 times. Recently many efforts have been made to establish cell lines with properties of their original cells of tissues. Production of serum protein is one of the most important properties of liver parenchymal cells. ${ }^{14,15)}$ In the culture media of YEL-8, -12, and -13 , we detected a protein which reacted with antiserum against Yamame serum. These facts indicate that YEL- cells have the properties of producing and releasing one of Yamame serum proteins into culture medium. Continuously growing cell lines derived from mammalian liver tissues often have stable function, some keeping their functions even after long cultivation, ${ }^{5,8)}$ while others losing their functions along with passage. ${ }^{4}{ }^{16)}$ Even after subcultured more than 120 times, it was confirmed that YEL-13 has been retained the property of production of the serum protein.

It is known that healthy Yamame (or masu salmon) has 66 chromosomes. $\left.{ }^{17}, 18\right)$ The chromosome number of YEL-13 cells ranged widely and most of them were between 50 and 83 . Such heteroploidy has not been reported in the tissues of Yamame. YEL-13 cell line suspected to be transformed and adapted to in vitro condition. But it is also well know that fish cell lines, which have been cultured for long period have varied chromsome numbers, if not cloned. ${ }^{19,20)}$

This cell line is supposed to consist of two or three cells morphologically. Cloning of the cells was not succeeded yet. An other liver functional study remain for further investigation.

The authors are grateful to Mr. N. Hasegawa, Yamaguchi Trout Farm for his supply with embryonated eggs and Miss Y. Nakayama for her excellent technical assistances. This work was supported on part by Grant-in-Aid for Scientific Research from the Ministry of Education.

\section{References}

1) C. Guguen-Gillouzo and A. Guillouzo: in 
"Isolated and cultured hepatocytes" (ed. by A. Guillouzo and C. Gugen-Guillouzo), John Libbey \& Co. Ltd., London, 1986, pp. 2-10.

2) H. Mitani and N. Egami: J. Fac. Sci, Univ. Tokyo, Sect V, 14: 391-398 (1980).

3) S. Hayashi and Z. Ooshiro: Niioppn Suisan Gakkaishi, 51 : 765-771 (1985).

4) I. Doi, M. Namba, and J. Sato: Gann, 66: 385-392 (1975).

5) I. Doi: Gann, 67: 1-10 (1976).

6) E. Athur and M. Balls: Exp. Cell. Res., 64: 113-118 (1971)

7) J. L. Fryer, A. Yusha, and K. S. Pilcher: Ann. N. Y. Acad. Sci., 126: 566-586 (1965).

8) S. Honma: Jikei Med. J., 32: 289-315 (1985),

9) D. H. J. Schamhart, K. W. van de Poll, and R. van Wijik: Cancer Res., 39: 1051-1055 (1979).

10) D. H. J. Schamhart, W. Berendsen, J. van Rijn, and R. van Wijik: Cancer Res., 44: 4507-4516 (1984).

11) H. Nakabayashi, K. Taketa, T. Yamane, M. Oda, and J. Sato: Cancer Res., 45: 6379-6383 (1985).

12) T. Watanabe, M. Nakano, H. Asakawa, and T. Moritomo: Nippon Suisan Gakkaishi, 53: 537642 (1987).

13) R. C. Feldhoff, J. M. Taylor, and L. S. Jefferson: J. Biol. Chem., 252: 3611-3616.

14) T. Tutamune: Acta Med. Okayama 29: 137-145 (1985).

15) H. Seibert: Comp. Biochem. Physiol., 4: 677683 (1985).

16) H. Seibert: Comp. Biochem. Physiol., 4: 877883 (1985).

17) J. Muramoto, J. Azumi, and H. Fukuoka: Chromosome Information Servce, 17: 20-23 (1974).

18) T. Ueda: Bull. Fac. Edu., Utunomiya Univ. 34: 53-61 (1983).

19) T. Watanabe, M. Sano, Y. Ishida, Y. Mizusawa, and M. Michikawa: Nippon Suisan Gakkaishi, 46: 1203-129 (1980).

20) T. Watanabe: J. Tokyo Vet. Anim. Sci, 32: 65-69 (1984). 